Portland State University

PDXScholar

2015

\title{
A Bird Flies Into a Pane of Glass Again and Again and Again
}

Zachary Cosby

Portland State University

Follow this and additional works at: https://pdxscholar.library.pdx.edu/honorstheses Let us know how access to this document benefits you.

\section{Recommended Citation}

Cosby, Zachary, "A Bird Flies Into a Pane of Glass Again and Again and Again" (2015). University Honors Theses. Paper 162.

https://doi.org/10.15760/honors.183

This Thesis is brought to you for free and open access. It has been accepted for inclusion in University Honors Theses by an authorized administrator of PDXScholar. Please contact us if we can make this document more accessible: pdxscholar@pdx.edu. 
Zachary Cosby

Honors Thesis

\section{Artist Statement}

This project began as a burst of enthusiasm for the possibilities of the prose poem, and ended as a search for a means to move beyond the tired (and tiring) american tradition. Upon reading my first pieces within the genre, I recall a feeling of limitlessness, as though removing enjambment from the work had the effect of compressing experience itself into a stream of images. The more I wrote for the project, the more I felt an overwhelming awareness of sameness. As I began to research the history of the american prose poem, from Russel Edson and James Tate, to anthologies and journals of contemporary work, I began to sense a pattern. The further the genre developed, the more it appeared formulaic. It felt as if the truly successful prose poem operated as if someone took a handful of their most personal items (a letter to a dying mother, an ape, a piece of yellow string, the landscape of a dream), put them in a box together, and shook them like dice in a cup. A prose poem, then, was the resulting mess that spills across the page.

I want a kind of writing that brings back temporal linearity and a speaking subject to the forefront of the work, while still retaining a playfulness and willingness to experiment that (by my definition) characterizes the poetic genre. Rather than moving in the direction of flash fiction, I was interested in finding ways to make everything smaller than before. I wanted these poems to capture the kind of sparseness and lucidity that was historically invoked by haiku and haibun forms, but today might be best exemplified by the still emerging stylistic quirks seen on twitter.com. Twitter forces the writer into concision, rewarding those who can 
create tiny worlds through the suggestibility of disparate words and ideas. Some living writers, such as Melissa Broder, have found immense success beyond their published poetic works in this medium, while other dead authors, such as Richard Brautigan, have found new life as their work is excerpted and presented in entirely new contexts.

For me, the challenge was in finding a middle ground between these two tendencies. Perhaps I am still very much indebted to the american prose poem, but the dream is to move beyond it. I try to embrace the minimalism, the temporality, and the speaking subject of contemporary internet writing and place it within the memory of what the prose poem once was. 
a bird flies into a pane of glass

again and again and

again

by

Zachary Cosby

An undergraduate honors thesis submitted in partial fulfillment of the requirements for the degree of

Bachelor of Arts

in

University Honors

and

Philosophy \& English

Thesis Adviser

Zachary Schomburg

Portland State University 
The role of the kiss is to never swallow what it craves

— Michele Glazer

A kiss is the beginning of cannibalism

- Georges Bataille 
cave 
i wake up in

caverns with no one around

to excavate your

ghost and flood this poem with

tar a photograph or ten

thousand dots of

ink

that i call a name 
is this poem a self-understanding or a truce

my arms are yellow paper folded

when my arms dip in water

they transform to something limp and disappointing

it rained through the funeral

everything felt incredible and large

a cup of coffee with the wreckage of lipstick

the smell from wet piles of clothes

so like swallowing a bird in flight 
a feeling tunnels through my body

a quiet landscape

a stillness like the space between wings

a stillness like the flooded cave

in this dream, my mouth filled with sand

my teeth bleed we wait for night

i ask for some kind of fire

you touch me like sleeping birds

it feels like the shadows below clouds 
below our skin hide lakes of blood

i am trying to remember how to escape

a place without sound or trees

i make a canoe from stone and sail it

i lay in the dark and cover my face with sheets

the lack of air hangs wet and crushing

why do memory pucker and bloom

i don't really know

don't really want to know 
the front door is locked at night

i lay in the yard a dead pale moth

winter parachutes from the sky

in this dream even icicles feel

the snow an endless plain of bones

i wanted someone to be with

so i held a picture of some strange face

and nailed it to my chest

somewhere an alarm was ringing 
our death friends are all hiding

i leave the house to look for them

they become statues partially hidden in fog

like a memory you told me

slipping in the rain while climbing the roof

to watch your dogs teeth the forest

our hands like wood grain in sun

we were not inside those bodies

we were those bodies 
imagine a number

that's how many dead deer

a forest could hold

we could walk hand in hand

through the trees

dumping our memory

like a landfill between branches

we could dig new landfills

into everything we touch

there is a phantom limb

growing through my mouth

but you can't see it 
we found a cave

no one had explored

you shined a light

but the cave swallowed light

you put your head in

but the cave swallowed you

i look to the sky

and try to find an outside

but there is no outside

and we are very small 
when i think about it

thick black fog

flows out of my mouth

thirty two teeth

looking for a way out

each of their cavities filled

with familiar sounds 
my lower half

a stomach cramp

a roadside bomb

spraying flesh confetti

maybe my body speaks

in strange languages

it's scared

to reproduce 
maybe gloom sunflowers

swallowed us whole

after three days

we woke in the belly

with hands and face smeared

in seed and pollen

please don't look away 
o' book of walt whitman's

infinite teeming womb

o' ebook of robert duncan gray's

abattoir of dreams 
the webcam model

we spent weeks watching

touch himself

on my computer screen

he was a giant beetle 
i thought mothheads

were my head

chewing through

your head 
i thought your teeth

were soft white linen

paper wings on fire

a slowly bleeding lamp 
tiny parasites

riot in my stomach

they gather in kerosene crowds

and hunger

they want to burn their home

just as their home wants to burn them

how do you make a person

stop living inside you

it's hard to talk about

without losing a face 
youth

i am outside looking in

the spinning particles

shaped like people

does everyone think about lips

pressing against skin

find me

behind the human 
i dream of the mole

just below your belly button

when i wake up

my lips are dry

the window is open

and a voice flows through

it is humming a song

in a minor key

there are patterns everywhere

that exist 
you can draw faces

from memory

it must be nice

to never feel alone 
what does a phone call mean 
magnolia trees

and the sunfucked dream

cemeteries are forests

radiating white noise

we stand like tall grass

in june 
make dead deer of us

when photograph collections

are broken time machines

the wind is not peaceful

when you blow on my arm

when do spinning particles

turn to chemicals

of people 
i wanted to drown

in waves of light

i planted flowers

in my skin

a tiny boy

became a tiny garden

and a tiny garden

became a tiny mouth

swallowing 
when you lose that body

a never fake death

take your time

and tweet something beautiful 
i try to swallow

every beautiful thing

but beauty disappears

inside a cave

bodies eat themselves

when starving

is cannibalism

beautiful too 
everything i touch

feels like oil black hair.

everything i write

sweats that first time we met.

all things

are made of skin. 
the carpets

a toothbrush

red candy

skin.

chat rooms

an erection

guilt smell

skin.

grocery stores

your best friends

the ocean

skin. 
windows

despite their transparency

are a different kind of skin. 
that immense feeling

of you on top

one hand on my hip

the other in my mouth.

that feeling

was always skin. 
we will evaporate

in the air as clouds

heavy with cum

and bile

and blood

i can see

my neighbor

he's raking

brown leaves 


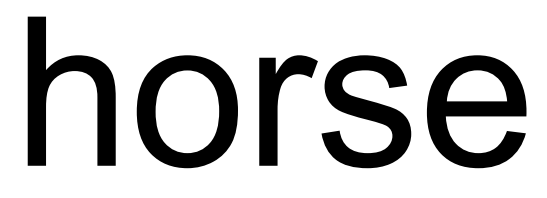


i write your name

in ink

and hope it never becomes

like the wallpaper

in the kitchen

of grandmother evelyn

that would fade

every summer heat

into pale ghosts

nobody could recognize

it was a beautiful name

for a grandmother 
i watch a sailboat erase the horizon

and finally understand enormity

the sun has stopped in the sky

my phone a face in glass 
my wrists in vases

of plastic flowers

they don't feel small

or beautiful

they feel like copies

of some dying thing

i wash my face

in the sink

i fall asleep

like wet ham

i use google to find you

give a new name

to something on the left

give a new name

to this book of poems 
sometimes i call my mother

and say everything will not be okay

i always hang up before she responds

but one time i said something different

i said death is the final horse

and laughed

it sounded like a swarm of bees

as thick as fog 
i have a nightmare about a horse and all my friends as beautiful marble statues

one of my friends is on her phone one of my friends is eating grapes one of my friends is laughing and laughing and all are beautiful marble statues

thirty seven beautiful marble statues frozen in thirty seven beautiful marble ways

i wonder what it's like to be invisible as i make a picnic for one over there a horse eating a field of grass 
there is a horse wandering through my home

i place my hands on the horse's face

and place my hands on the horse's neck

when the mouth opens

wood vibrates like ten thousand bees

or clouds 
a man walks to the horse

with a revolver in his hand

he presses the revolver

to the head of the horse

and whispers run 
my own fingers fold

in the shape of a gun

the air is punctured

by the screaming of horses 


$$
\text { deer }
$$


nothing exists outside of experience which is to say this poem is the space outside of masks a gun fired into open sky reading missed connections 
i tell myself to write poems but I don't even like poems

there is nothing in the act of poem

why cannibalize memory for the sake of nothing

to eat a clementine alone in the dark

i put on a shirt

something necessary 
$i$ think this face is not my own

$i$ think this face is not my own

$i$ think this face is not my own

$i$ think this face is not my own

a bird flies into a pane of glass

again and again and

again 
my neighbor

is holding a rake

like a mannequin

a dead deer crumpled

through the hood

of my car

the sun is black

in a sky of black

over a crayon

also black 
something is moving

behind the cans

in the pantry

if you want

to know something

it helps to name it

helps to touch it

i am amazed

how antlers don't bleed 
my neighbor is

raking a field of rakes

i ask what he is doing

he points to the stars and the satellites

the night is for sleeping

and the day is for staying alive

it goes back and forth like this

for a very long time 
i make a mountain of meat

that takes a lifetime to climb

i can see my neighbor

between two little houses

that little house is mine

that little house

is not 
i make friends with a child

at the peak of the mountain

we share a common enemy

whose name we do not speak

our story is a ghost story

the kind a child

tells another child 
a child wears a deer head

like its own head

i wear my head

like my own head

my neighbor

is raking the rakes 
a child asks

about my face

a face

is a face

is a face

is a face

except 
dead deer fall from the sky

and smack against our homes

a body falls apart

like a handful of flowers

pushed against a face

until it undoes 
i see my neighbor

with black shirt

soaked in black fog

i want to save him

want to know

his name 
i walk down meat mountain

below a black cloud that spreads

from this horizon

to that horizon

and that horizon

and that horizon

i clutch an umbrella to my chest

wow says a child

dead deer follow you everywhere

and we laugh

it was true 
there is a portal to hell

in the corner of my bedroom

everything smells

a man that looks nothing like my father

puts a hand on my shoulder

it was a very funny joke 
you had a dream of hostile billboards

we ran through new york in abstract fear

the faces on magazine covers glaring

we caught eyes like late spring pneumonia

we were 900 channels of television and worshipping the sound

of white noise breaking beyond our frame 
i'm going to vancouver this afternoon

i wash deer blood off the hood of my car

i take a picture of me and my world

i like the thought of losing five, maybe ten pounds

consider replacing friends with plants

a change of surroundings would be nice

like opening a new tab 
a tiny piece of glass cuts my right foot

it was shaped

almost nothing like the rays of the sun

passing through the window

i remember your name 
i pour and pour away

the blood

feeling more like ghost

than the death that births it

slow

and incredibly far away

you would like it here

like how

alone it can feel 
my body

no longer inside

this mannequin

hex 
citrus 
the

name

of

this

poem

is

citrus 
i retire my lips

in a gesture of goodwill

towards those i fucked over

they live

their final days

inside a cave

with the memory

of red grapefruit

tongues

the ghosts they birthed

live on

as friction burns

on the skin of horses

a name

is a terrible thing

i hope a name

never becomes true 


\author{
this is a forest fire of \\ paper cigarette ebooks dog \\ feces coffee street litter cables \\ reducing my head \\ to charred neurons stumps \\ and ash habitats.
}

once i found a moth

in the glow of your cellycell's

flashlight app

it flew inside my mouth

and recited a poem 
moth poem

blue screens of death

flash inside your eyes

digital flowers bloom

black between our thighs 
even these things

that i want

i don't really want

i think

i'm trying to say

that $\mathrm{i}$ want

to stop wanting

avoid

like a void

trying to swallow

another void 
he says

i want to leave you with a virus

that doesn't scrape off

he does

it won't 